\title{
A framework to build readers and wri- ters in the second language classroom
}

\author{
Gilma Zúñiga Camacho \\ silmazuniza@usco.edu.co \\ Universidad Surcolombiana
}

\begin{abstract}
This article proposes a framework to create readers and writers in the second language classroom. The components of the framework are curriculum, instruction and assessment. The curriculum states the goals and philosophy of the program that intends to create lifelong readers that find reading as a source of entertainment and information. It will also include the kind of literacy that the curriculum wants to support, the effect of reading in the first language, and the use of appropriate materials to achieve the goals. Instruction is framed under principles like reading is thinking and learning, reading and writing are taught together, and technology influences reading and writing development. Assessing reading in the second language classroom is the next component of the framework discussed in the article and it proposes the use of authentic tools like portfolios and observations. Traditional tools like tests are also mentioned.
\end{abstract}

Key words: literacy, second language, curriculum. critical reading, lifelong reading, instruction, assessment. 
Este artículo propone un marco de referencia para crear lectoescritores en el aula donde se enseña una segunda lengua. Los componentes son el currículo, la enseñanza y la evaluación. El currículo establece los objetivos, y la filosofía del programa de lectura y también pretende el desarrollo de un lector crítico, que encuentra en la lectura en segunda lengua una fuente de información y entretenimiento. El currículo también tiene en cuenta el efecto de la lectura en primera lengua sobre la segunda, y el uso de materiales adecuados para el logro de los objetivos. La enseñanza está enmarcada en principios tales como la lectura y la escritura se enseñan simultáneamente, y la tecnología influye en el desarrollo de la lectoescritura. La evaluación de la lectura es el siguiente componente, y propone el uso de instrumentos auténticos tales como el portafolio y la observación. Se menciona, además, el uso de instrumentos tradicionales tales como los exámenes.

Palabras claves: Lectoescritura, segunda lengua, currículo, lectura crítica, lectura para toda la vida, enseñanza, evaluación.

\section{INTRODUCTION}

The past decade has seen numerous efforts to restructure or reform school and licenciatura English programs in Colombia. Some of these efforts have been spurred by dissatisfaction with student performance in learning English (COFE PROJECT, 1992), others by research findings that have provided educators with additional information about how to create, implement, and assess instructional programs. Still other restructuring plans have evolved through the efforts of teachers who have been encouraged to become directly involved in decision making in the schools and pressed by a society that is demanding more proficient English users at all levels of education.

Developing a reading program in the second language classroom is a task teachers can undertake successfully. It necessitates a deep knowledge and understanding of language acquisition, research in English language learning, and effective instruction strategies. Reading in the second language classroom helps to consolidate students learning of the second language and, at best, increases their proficiency. In learning English as a second language, the mastery of reading and writing are key skills necessary to build the whole language 
development therefore, this article will provide a framework to create readers and writers in the second language classroom at any level of education.

Why reading and writing? Because the children of the twenty first century will face many challenges that will require them to use reading and writing in English in different forms. As we begin the new millennium, teachers are learning research-based approaches to teach reading and writing that will prepare their students for the future. Furthermore, second language reading instruction can and should allow students to develop into fluent, independent, and confident second language readers, and finally, reading classes can give students a love for reading in the second language, a thirst that will stay with them throughout their lives (Day, \& Banford, 1998). We must teach students the processes of reading and writing, as well as how to use reading and writing as learning tools. Bill Teale (1995) challenges us to teach students to think with and through reading and writing, and to use reading and writing for pleasure and insight.

Reading in a second language has not been usually successful. Aud Marin, as cited by Day, E Banford, 1998) points out: "There has been a tendency among foreign language learners to regard a text as an object for language studies and not as object for factual information, literary experience or simply pleasure, joy and delight". In Colombia, for instance, despite the new trends in communicative teaching, reading is still practiced in most state schools to reinforce grammar, to read dialogues, words and sentences or to do literal translation of words. Those are the results reported by three research studies carried out by Cardona and Quintero (1996) in Manizales, Zambrano, E Insuasty (2001) in Neiva, and Bastidas (2002) in Pasto. Those studies also showed that reading is still taught not to learn new information, that reading is confined to reading sentences in a notebook, from the blackboard or from guides or instructions to do an exercise. Meanwhile, writing is used to copy sentences from the blackboard or develop exercises or guides, requiring not much thought. Those reports also concluded that activating prior knowledge or reading with a purpose are absent of reading classes. Besides many times basic skills like scanning, and skimming are also unknown, and reading materials do not go further than the textbook.

This article will consider how we as teachers can approach reading and writing in the second language classroom, not only as fundamental founda- 
tion for language learning but for helping learners become literate people who undertake reading in English as a life long endeavor. The framework proposed here provides three components that can be followed at any educational level. They are curriculum, instruction, and assessment.

These elements of reading in the second language program must be based on a broad comprehensive view of how students learn, and be based on a comprehensive understanding of the reading process. It also requires a vision of what reading is, selects literacy goals and have the competence and commitment to develop instructional plans that will help students achieve those goals (Bean, 1995).

\section{CURRICULUM}

The reading curriculum is the plan for guiding learning in the school; it provides the ideas for charting the directions for the classroom. The curriculum includes the goals and philosophy of the program and the student outcomes identified as important. The outcomes include the understandings, skills, and attitudes that the school wishes students to achieve. Also included in the curriculum are the materials that facilitate achievement of goals. Described below are guidelines that reading teachers in the second language classroom might wish to consider.

\section{The school must decide upon goals for reading instruction based upon a sound definition of the reading process.}

Harste (1989) suggests that a balanced reading curriculum is based on our understanding of reading and writing and the concept of literacy. Experts agree that reading is not simply a hierarchically arranged set of subskills easily taught and tested, but rather a complex activity requiring the coordination of a number of interrelated sources of information (Alderson, (1992).

Reading is a constructive process, must be fluent, must be strategic, requires motivation, and is a continuously developing skill (Alderson, 1992). A curriculum based on this consideration suggests an emphasis on providing students with many different purposes for reading, and with a variety of texts. They stress the importance of self monitoring and motivation in the reading program. The importance of a reading program is apparent when one under- 
stands that becoming a reader is a lifelong pursuit, requiring much practice and refinement, particularly in this technological society with its sophisticated demands of the adult reader (Bean, 1995). The previous considerations assumed for reading in first language could be assumed for reading in the second language classroom if teachers are to use reading in the second language classroom in a meaningful way that contributes to shape students into literate people able to function according to the demands of new societies.

What kind of literacy does reading in the second language classroom want to support? Let's start, with some definitions. What is literacy? "Literacy" used to mean knowing how to read, but the term has been broadened to encompass both reading and writing. Now literacy means the competence to "carry out the complex tasks using reading and writing related to the world of work and to life outside the school" (Cases in Literacy, 1989, 36). And according to Rafferty (1999), "literacy is a tool, a way to learn about the world and a means to participate more fully in the technological society of the twenty-first century". The need for critical literacy has been claimed by researchers, such as Freire, who refers to the direction of functional skills towards the ability to mount a personal critique of all those issues which surround us as we live, learn and work, issues that help us understand, and ultimately control the direction of our lives (Green, 2001).

Green (2001), also states that critical literacy may involve a number of objects of critique, such as knowing literacy critically, viewing particular texts critically, and or having a critical perspective on the social practices involved in literacy use. Thus, texts and literacy as social practices are highlighted within critical literacy. A critical literacy stance argues for an active, challenging approach to literacy. One such approach pertains to the critical reading of texts, which can enable students to become aware of the way in which texts are constructed and how such constructions position the reader.

Although clearly a number of potentials exist within critical literacy, the translation of such theory into practice is not easy. Within the context of the classroom, critical literacy offers a critical approach to text, language of critique or a critical discourse, and examination of literacy across content areas. However, before critical literacy can occur within the second language classroom, students need the opportunity to engage in meaningful use of literacy, or in other words, to use literacy in ways that relate to their interests 
and needs. Without the opportunity to read, and write for a range of purposes, with access to a variety of texts, there is no basis upon which critical discussion of and reflection on literacy can occur.

To sum up, in a curriculum for reading in the second language classroom, the goals framed under a sound theory of reading, and the reading of texts lead students towards becoming literate people, able to function successfully according to the new demands of the society.

The reading process was defined in terms of first language reading, but what happens when a student reads in the second language? This is the next topic considered in the curriculum. How is reading in English as a second language affected by reading in Spanish as a first language?

\section{Reading in English is affected by reading in Spanish}

"There aren't really any differences (between reading in English and in Spanish), I mean they are both based on the same thing, how you understand it, how you read it, how you take it, and how you evaluate it and all that." Alberto, Hispanic middle school student in the United States.

Most experts agree that the skills the students have in their first language are a solid academic and personal foundation necessary to acquire the second language (Eldesky 1986). Furthermore, reading in first and second language are similar processes that share many things in common. Both are meaning making processes from printed texts. Both are transactions between the reader, the text and the context. Both depend on prior knowledge, need knowledge of cue systems, use cognitive and affective strategies and both are vehicles to getting or changing knowledge. There is a consensus that there is a transfer of reading from the first language to the second and that teaching reading skills in the native language may facilitate the transfer (Day $E$ Bamford, 1998).

Chamot \& O'Malley (1994) advice teachers to find out about students skills, habits and attitudes to reading in their first language. They suggest to collect information on the students' literacy skills in their first language by finding out as much as possible about the students' level of literacy in their native language and their experience with literacy tasks. Teachers can get information from other teachers or from parents about students educational background and literacy. For students who are literate in their first language, teachers will 
be able to draw parallels between the first language and English by teaching the students to use cognates that may exist between the two languages. While inferring the meaning of unfamiliar words, and to use the strategies that were most effective for them in comprehending and retaining information from print materials in their native language.

New trends in research in Colombia are also dealing with reading in Spanish and English. This is happening in Bogotá with the work done by Amparo Clavijo (2000) in projects carried out under her guidance with titles like: "Construyamos inglés como segunda lengua partiendo del desarrollo de la lectoescritura de la lengua materna", "El uso de textos literarios en el desarrollo del proceso de lectoescritura y en la enseñanza del ESL", "Turismo bilingüe por mi ciudad capital". Some conclusions drawn by these works state that:

- Reading in Spanish and English are similar processes

- Reading and writing in both languages need activities that should be contextualized in the classroom

- Reading and writing in both languages are mediums to express thought

- Processes in both languages require a socioaffective factor

- Prior knowledge is important in both languages

- Both languages require meaningful contextualized pedagogical situations

- Reading and writing are thinking process that are used through social interaction

- Technology is shaping reading and writing in both languages

- The use of authentic texts like letters, poems, stories, jokes, recipes, graffiti, and advertising serve multiple purposes in reading and writing.

Reading in Spanish as a first language, can guide the second language teacher towards a more efficient reading in English that can be an enriching and supporting as shown earlier.

The last element considered in the curriculum is the use of materials. Materials that help teachers, and students achieve the goals for creating suc- 
cessful readers and writers in the second language classroom.

3. Materials should be chosen to help schools achieve their reading goals.

A study about reading in first language (Yopp \& Yopp, 1991), claims that providing students with motivating materials and involving them in a variety of interesting activities are critical to a successful reading program. The same can be said for second language reading programs. Without reading materials that are attractive, interesting, at a range of appropriate levels, and of an appropriate length, a program cannot exist. When making decisions about specific types of materials for specific students, teachers can consider these questions (Day \& Bamford, 1998):

- Will this material attract them?

- Do my students have enough language and background knowledge to be entertained or informed when reading it on their own?

- In terms of their self image as readers, will reading it be an encouraging or a discouraging experience?

Some of the major categories of material potentially useful for reading in the second language classroom are: Literature adapted for language learners, children's books, designed to teach children to read in their first language. These books are usually very attractive and can add variety to any reading. Learner's own stories, written by students and given for reading by other students in the lower classes. Newspapers can be a superb resource for intermediate and advanced students, particularly for reading outside the classroom. The layout, content categories and organization are similar across many cultures, which makes reading easier. Magazines are usually colorful and attractive, and their visual emphasis can help readers understand the content. Adults prefer magazines to read, and research studies have also identified magazines as adolescents favorites to read (Ivey E Broaddus, 2000), therefore school and classroom libraries should have plenty of these materials. Translations, often overlooked, is literature that has been translated from the students first language into the second language. An advantage of translated books is that the characters, the plot, and much of the vocabulary will be familiar to the students if they have read the original. Books should not be long, available in 
different levels and in all genres. We need to convince our students that the task ahead is not an impossible one.

The three guidelines discussed above in the curriculum, provide a skeletal outline for WHAT needs to occur in any reading program in the second language classroom. It is also imperative to think about HOW the curriculum will be delivered, that is how instruction will take place.

\section{INSTRUCTION}

Any discussion of instruction needs to include a description of the learning strategies, and organizational arrangements that help teachers meet the needs of individual learners. Teachers must have an excellent understanding of the reading process as well as reading instruction. The following principles may help teachers design teaching strategies that are framed under these theoretical principles: Reading is thinking and learning, reading and writing are taught together, and reading and writing classes in the second language classroom should incorporate technology.

\section{Reading is thinking and learning}

The following considerations about reading in first language might be useful for the second language teacher if he/she wants to create the conditions to make reading classes meaningful. Reading promotes thinking and learning and the most important factor in determining how much readers will comprehend a text is their level of knowledge about the topic. The importance of prior knowledge to comprehend and communicate is included in virtually all modern theories of reading. According to schema theory, prior knowledge provides a schema -a framework or structure- that helps thinking.

Because communication and comprehension are so prior-knowledge dependent, children whose knowledge of a variety of topics is limited have difficulty comprehending much of what they read and difficulty communicating in writing about many topics. Furthermore, but children who read little have the least opportunity to acquire new knowledge through reading and therefore understanding more when reading.

Reading comprehension in elementary and secondary schools usually 
entails teaching the central idea of a paragraph of a text and the construction of literal meanings for the text and in an effort to obtain accurate recall and understanding. As a result, students learn to reproduce information for the examination, but not to relate experience to it, or to reorganize it into more coherent or more useful schemata, that is to link reading, thinking, and learning. (Pirozzolo \& Wittrock, 1981).

Learning new knowledge is the goal of reading. Texts written to inform can excite the younger reader as well. Children do wonder about their world, and texts can be a source of both satisfaction and stimulation for their curiosity. Texts written to inform can be a source of both satisfaction and inquiry (Hoffman, Bauman \& Afflerbach, 2000).

Texts help to the identification and solution of relevant problems from the concrete world. Students can get information that is important to understanding the world through grappling the real world problems. Reading is a tool to foster growth in content knowledge and integrating reading into the content areas such a science and social studies throughout the day can facilitate children's higher level thinking.

\section{Reading and writing are taught together}

There is a broad consensus in the relationship between reading and writing. Most experts agree that, although not identical, reading and writing are similar and mutually supportive language processes (Butler and Turbil, 1984). Both rely on the reader's or writer's background knowledge to construct meaning and both make use of cueing systems (graphic, semantic, syntactic) to allow the reader or writer to predict and confirm meaning. Traditionally, reading and writing have been viewed as two separate processes with little in common, however much of the research is guided by the theory that both reading and writing involve meaning making (Shanahan, 1997).

The fact that both reading and writing processes share similar cognitive stages, specifically planning, drafting, aligning, and revising has pedagogical implications for classroom teachers who can take advantage of these similarities and integrate them, thus enriching not only both linguistic skills but language learning in general. A theoretical approach to the interrelationship of reading and writing processes suggest that both processes are constructive and developmental processes; both require learners to use prior knowledge and interpre- 
tative skills to grasp the author' s meaning, utilize self-directed feedback, and employ the reciprocal transitive process. According to Wittrock, E Pirozollo (1981), "readers and writers develop meaning by constructing relationships between the text and what they know, believe, and experience" (p. 77). When writers compose, they use text to convey information. Writers produce texts with structure; readers use structure when they construct meaning.

In his influential study about the relationship between reading and writing, Stostsky (1983) concluded that (1) good writers tend to be better readers than are less able writers, (2) good writers tend to read more frequently and widely and to produce more syntactically complex writing, (3) writing itself does not tend to influence reading comprehension, but when writing is taught for the purpose of enhancing reading, there are significant gains in comprehension and retention of information, and (4) reading experiences have as great an effect on writing as direct instruction in grammar and mechanics.

\section{Technology influences reading and writing in the second language class- room.}

Today, the Internet is a handy tool that could be extremely useful in the second language classroom and in the future it will be indispensable. Access to the Internet provides an opportunity to enhance students' reading and writing proficiency and to promote their skills in information gathering and problem solving (Ryder \& Graves, 1997).

However, a high demand of thinking critically is needed as students surface the web. They need to identify safe and accurate domains like .gov. or .edu. They should learn to look for the author and to question his/her credentials. They need to question an organization motives. Are there emotional statements? Are they trying to sell me something? Are they con or pro on the information provided? Are these facts or opinions? (Cox, 2001).

Besides, new strategies for organizing information will be needed. The Internet has no organizational principle, then the student has to choose paths to follow. The organizational principle is the learner's interest in seeking the information. His/her ability to apply existing knowledge and to construct meaningful representations of the information encountered will be essential. High level of thinking will be required for the student to direct attention to specific information using his/her cognitive maps and frames. The critical use 
of the new technological advancements will equip the student not only for the workplace but personally and culturally.

The real potential of the Internet lies in its ability to provide both a foundation for language learning that is abundant with authentic textual material and, simultaneously, the means and motivation for this material to be used. Allowing easy access to multiple cross-references on related topics across several documents or screens, hypertext links contained on Internet pages, provides a networked environment in which students are encouraged to read widely. As students engage in extensive and intensive reading, vocabulary and language structures become increasingly familiar, intertextual associations become clearer, and broader base of schematic knowledge is developed.

To direct students' search, they can ask themselves questions like: Does the information add anything to what you already know about the topic? Who is providing the information contained on the Internet page? Where did the information come from? Do they provide evidence to support the points they are making? How old is the information? Who recommended the site as a good source of information?

Writing is a neglected skill in the second language classroom, but the use of the Internet can provide excellent and real possibilities to read and write real things to real people (Velasquez, 2002, Wood, E Tiller, 2000). Wepner, Feenley, and Strickland (1995) also claim that a second role that technology might play is to expand opportunities to engage children in reading and writing real things. The computer can solve difficulties associated with composing, revising, editing, and publishing work. Participating in pen-pals or networks increases the mount of reading and writing children do and therefore the access to an enormous set of informational resources.

Students in Colombia are also turning to the Internet as a source of information, as shown by a survey given to some students and recently graduates from 4 licenciatura programs in English (Zuñiga, 2002). According to its results, $98 \%$ of the population surveyed said they read through the Internet an average of 3 hours a week. The most common readings were newspapers, being the New York Times the favorite, current affairs, information about scholarships, job opportunities, teaching issues, and music.

The philosophy and the goals have been stated in the curriculum, then through instruction we have discussed how this curriculum could be carried 
out. Now let's discuss how we can measure the outcomes of reading programs, through assessment.

\section{ASSESSMENT}

By nature, assessment allows for inquiry into the reader's and writer's knowledge and provide ongoing information about a reader's growth over time (Crafton, 1994). Assessment is an integral part of teaching and learning and the purpose of classroom assessment is to inform the teacher and influence instruction. Through assessment, teachers learn about their students, about themselves as teachers, and about the impact of the instructional program. Similarly, when students reflect on their learning and use self-assessment, they learn about themselves as learners and as well about their own learning (Tompkins, 1997).

A reading program generally includes two broad categories of reading assessment: assessment designed for external accountability and assessment designed for instruction, or internal assessment. External assessment using standardized tests are used to make judgments about the school reading program. Internal assessment is used by the classroom teacher to make decisions that affect daily lessons and is closely linked to the curriculum and the instruction that occurs in the classrooms.

Testing students skills knowledge is certainly an important part of education, but it is only a part of educational assessment. Standardized tests is one way of testing that is commonly used in the United States, and is gaining popularity in Colombia as many students from universities and secondary schools are required to take standardized tests in English. Standardized tests were designed originally to make normative comparisons across large numbers of students, not to diagnose the skills of individuals.

Allington $\mathcal{E}$ Cunningham (1996), claim that standardized achievement tests have two basic uses. Test scores are often used to rank-order school performance and, inappropriately, to rank-order individual children's performance. Standardized tests would suffer some problems of validity. Such tests do not measure everything that students might know or be able to achieve. In fact, standardized tests assess only a narrow range of the reading processes that students are expected to develop. Such tests do not measure, for instance, 
whether students read widely across a variety of genres, authors, and topics. They do not tell us whether students can discuss what they have read or synthesize across texts or compare one author with another. The tests do not really tell us about reading habits or strategies that students might use. They do not provide much information about comprehension processes since the tests measure only the lowest level cognitive processes operating on short pieces of text. They do no tell us about whether students have refined strategies for selecting books or locating materials to pursue developing expertise on a topic. In short, current tests measure only a few aspects of reading development.

However, standardized tests have advantages too. Standardized tests rest on a number of factors (Hoffman, Bauman, $\mathcal{E}$ Afflerback, 2000). They are easy to administer and score. They provide data more directly and efficiently than from alternative assessments. This feature makes the data easier to interpret when comparing performance across groups of students or across time. Furthermore, we have come to understand that different assessments are useful for different purposes. If we want to gather information to assist with classroom instruction, we must use classroom assessment that is appropriate in content and method.

Because standardized tests provide limited information about what a reader can do, teachers are now turning to alternative or more authentic forms of assessment, such as daily work, interviews, conferences, anecdotal record keeping, and development of student portfolios. Such assessment should be authentic, that is, it should include opportunities for students to demonstrate their ability to perform real literacy tasks. Students, therefore, can be observed as they read orally; they can be asked to write in response to a selection or they can recall the most important ideas from a text. Teachers can use all of these measures to develop portfolios to document student's growth over time.

Alternative literacy assessment contextualizes literacy tasks, links instruction with assessment, and promotes greater student involvement. Another advantage of alternative assessment is to provide teachers with knowledge about students' strengths and needs that will positively inform their instruction.

Curriculum, instruction, and assessment form the essential core of the reading program in the second language classroom. They provide the framework for developing, implementing, and evaluating any program. 


\section{CONCLUSION}

Creating readers and writers in the second language classroom is not an easy task. However, stating a framework that includes a curriculum, instruction and assessment guidelines can lead to successful reading. A curriculum that is based on sound theory of reading, set attainable goals, and use the right materials can prove successful if teachers want to help students develop reading habits in the second language, reading that is rewarding, enjoyable, and undertaken as a lifelong pursuit.

Teachers that find themselves reading in the second language rewarding, are open to change and undertake new challenges like the use of new technologies for reading and writing, can help their students find the right paths to follow, in their way to become literate people of the twenty first century.

Reading in the second language classroom can move from a vehicle to study the language into a source of pleasure, entertainment, and knowledge, which also invites to examine our values and to take action on issues that we should address as individuals living in and contributing to a democratic society.

The theoretical framework proposed in this article has been applied in a research study carried out at Universidad Surcolombiana with 280 students from sixth grade in Colegio Departamental Femenino. Through action research, this framework has proved successful where most students are becoming good readers in both languages, Spanish and English.

\section{REFERENCES:}

Aebersold, J. A., \& Field, M. L. (1997). From reader to reader teacher. New York: Cambridge University Press.

Afflerbach, P.(2000). Teacher's choices in classroom assessment. In S. J. Barrentine (Ed.), Reading assessment: Principles and practices for elementary 
teachers (pp. 68-72). Newark, DE: International Reading Association.

Alderson, J. C. (1992). Guidelines for the evaluation of language education. In J. C. Alderson \& A. Beretta (Eds.), Evaluating second language education (pp.274-304). Cambridge: Cambridge University Press.

Allington, L. R., \& Cunningham P. (1996). Schools that work. New York: Longman.

Bean, R. M. (1995). Effective reading program development. In Wepner, S., Feeley, J., \& Strickland, D (Eds.) The administration and supervision of reading programs. New York: International Reading Association.

Bastidas, J. A. (2002, October) What research is uncovering about motivation. Paper presented at the $37^{\text {th }}$ ASOCOPI Conference of English Language Teaching, Cucuta, Colombia.

Butler, A., \& Turbill, J. (1984). Towards a reading-writing classroom. Portsmouth, $\mathrm{NH}$ : Heinemann.

Cardona, G., \& Quintero, J. (1996). Una mirada investigativa al aula de inglés. Manizales: Universidad de Caldas

Chamot, A. U., E O’Maley , M. (1994). Instructional approaches and teaching procedures. In K. Spangerberg-Urbschat and R. Pritchard (Eds.), Kids come in all languages: Reading instruction for ESL students. Delaware: International Reading Association.

Cases in literacy: An agenda for discussion. (1989). Newark, DE: International Reading Association and the National Council of teachers of English.

Clavijo A. (2000). Formación de Maestros, Historia y vida. Bogotá: Plaza E Janes en convenio con la Universidad Distrital.

COFE Project.(1992). A proposal of a framework for the teaching of English in the Colombian B. A. program. Unpublished document 1. London: Thames Valley University

Cox, K. (2001). Holocaust unit takes $8^{\text {th }}$ grade students to the Web. Cougars, 2, 2-3.

Crafton, L. K. (1994). (Ed.). Inquiry-based evaluation. Primary Voices K-6, 2(2),

Green, P. (2001). Critical literacy revisited. In H. Fehring, \& P. Green (Eds.), 
Critical literacy. Norwood, South Australia: International Reading Association

Hoffman, J.V., Bauman, J. F., E Afflerbach, P. (2000). Balancing principles for teaching elementary reading. Mahwah, NJ: Lawrence Erlbaum Associates Publishers.

Ivey, G., \& Broaddus, K. (2000). Tailoring the fit: Reading instruction and middle school readers. The Reading Teacher, 54, 68-78.

Pirozzolo F., \& Wittrock, M. (1981). Neuropsychological and cognitive processes in reading. New York: Academic Press.

Rafferty, C. D. (1999). Literacy in the information age. Educational Leadership, 57, 22-25.

Ryder, R. J. \& Graves, M. F. (1997). Using the Internet to enhance students' reading, writing, and information gathering skills. Journal of Adolescent and Adult Literacy 40, 244-255.

Shanahan, T. (1997). Reading-writing relationships, thematic units, inquiry learning: In pursuit of effective integrated literacy instruction. The Reading Teacher, 52, 12-19.

Stotsky, S. (1983). Research on reading/writing relationship: A synthesis and suggested directions. Language Arts, 60, 627-642

Teale, B. (1995). Dear readers. Language Arts, 72, 8-9.

Tompkins, G. (1997). Literacy for the $21^{\text {st }}$ century: A balanced approach (2nd ed.). Columbus, Ohio: Merrill Prentice Hall.

Velasquez, J. (2002). Integrating E-mail projects to the English classroom: Looking for intercultural understanding. Colombian Applied Linguistics Journal $4,78-84$.

Wepner, S. B., Feeley, J. T., Strickland, D. S.(1995). The administration and supervision of reading programs ( $2^{\text {nd }}$ ed.). New York: Teachers College, Columbia University.

Wittrock, M. C. (1984). Writing and the teaching of reading. In J. M. Jensen (Ed.), Composing and comprehending (pp.77-83). Urbana, IL: National Council of Teachers of English. 
Wood, L. S., E Tiller, D. A. (2000). The keyboard to success: An ESL /Basic writing Internet partnership. In L. Kasper (Ed.), Content-based college ESL instruction Mahwah, NJ: Lawrence Erlbaum Associates Publishers.

Yopp, R., E Yopp, H. (1991). Ten best ideas for reading teachers. In E. Fry (Ed.), Ten best ideas for reading teachers (pp. 132-134). Reading, M. A.: Addison-Wesley.

Zambrano, L. C., E Insuasty, E. A. (2001). Aplicación del enfoque comunicativo a la enseñanza-aprendizaje del inglés en los establecimientos de secundaria de Neiva. Entornos, 14. Universidad Surcolombiana p.p. 27-32.

Zúñiga, G. (2001). Constructing literacy from reading in first and second language. Neiva: Oti impresos.

Zuñiga, G. (2002) Reading in English: New roles in shaping Colombian literacy. Paper presented at the $37^{\text {th }}$ ASOCOPI Conference in English Language Teaching. Cúcuta, Colombia.

\section{THE AUTHOR}

Gilma Zuñiga Camacho, Master in Applied Linguistics to Teaching English Universidad Distrital Francisco José de Caldas, professor in the Modern Languages Department, at Universidad Surcolombiana in Neiva. 